\title{
OPEN A New Picture of the Global Impacts of El Nino-Southern Oscillation
}

\begin{abstract}
Jialin Lin ${ }^{*}$ Taotao Qian
The EI Nino-Southern Oscillation (ENSO) is the dominant interannual variability of Earth's climate system and plays a central role in global climate prediction. Outlooks of ENSO and its impacts often follow a two-tier approach: predicting ENSO sea surface temperature anomaly in tropical Pacific and then predicting its global impacts. However, the current picture of ENSO global impacts widely used by forecasting centers and atmospheric science textbooks came from two earliest surface station datasets complied 30 years ago, and focused on the extreme phases rather than the whole ENSO lifecycle. Here, we demonstrate a new picture of the global impacts of ENSO throughout its whole lifecycle based on the rich latest satellite, in situ and reanalysis datasets. ENSO impacts are much wider than previously thought. There are significant impacts unknown in the previous picture over Europe, Africa, Asia and North America. The so-called "neutral years" are not neutral, but are associated with strong sea surface temperature anomalies in global oceans outside the tropical Pacific, and significant anomalies of land surface air temperature and precipitation over all the continents.
\end{abstract}

The dominant interannual variability of global climate system is $\mathrm{ENSO}^{1-7}$, which plays a central role in seasonal to decadal global climate prediction ${ }^{8-15}$. Currently, outlooks of ENSO and its impacts generally follow a two-tier approach. The first step is to predict ENSO sea surface temperature (SST) anomaly in tropical Pacific Ocean, and the second step is to predict the global impacts of ENSO SST anomaly. The second step is the focus of this study.

The widely-used schematic of global impacts of ENSO is from Trenberth et al. ${ }^{8}$. It is being used by major international and national climate prediction centers such as National Centers for Environmental Prediction (NCEP) Climate Prediction Center (CPC) ${ }^{9}$, International Research Institute (IRI) ${ }^{10}$, NOAA Pacific Marine Environmental Laboratory (PMEL) ${ }^{11}$, and UK Met Office ${ }^{12}$. It is also being used by many public education websites such as the World Meteorological Organization (WMO) ENSO website ${ }^{13}$, U.S. Government's Global.gov ${ }^{14}$, NOAA's Climate. gov $^{15}$, as well as most, if not all, atmospheric science textbooks.

However, the schematic of Trenberth et al. ${ }^{8}$ is a summary of the pioneering works of Ropelewski and Halpert $\left(1986^{16}, 1987^{17}, 1989^{18}\right)$ and Halpert and Ropelewski $(1992)^{19}$, which were based a single dataset - the World Monthly Surface Station Climatology (WMSSC) dataset compiled by National Center for Atmospheric Research (NCAR) in the 1980 s, supplemented by Aceituno ${ }^{20}$ for South America stations. In the past 30 years, many new surface station datasets have been collected, many satellite measurements have been made, many new techniques have been developed for constructing global analysis, and many high-quality global reanalyses became available. In addition, the current picture focused on extreme phases of ENSO (El Nino and La Nina) rather than the whole ENSO lifecycle $8,21,22$. Therefore, time is ripe to revisit the picture of global impacts of ENSO lifecycle.

Here, we demonstrate a new picture of the global impacts of ENSO throughout its whole lifecycle based on the rich latest satellite, in situ and reanalysis datasets. See Methods section for details about the datasets and analysis methods.

Figure 1 illustrates the evolution of global SST with ENSO lifecycle using 137 years (1880-2016) of ERSST data. Similar results are obtained with COBE2 SST (Supplementary Figure 1) and HadISST (not shown). These are updates of the analysis of Lin and Qian $(2019)^{23}$ using the old Kaplan SST data, which did not cover well the southern hemisphere high latitudes (poleward of $40 \mathrm{~S}$ ). Figure 1 clearly shows the evolution of significant SST anomalies around the globe throughout the ENSO lifecycle. At lag 0 year (Fig. 1e), which is the peak of El Nino, the ERSST data shows better the global SST pattern with warming over tropical central/eastern Pacific and northeast Pacific, but a "horseshoe" cooling pattern over western Pacific, northwest Pacific and southwest Pacific. In particular, the ERSST data shows a wave train pattern in Southern Ocean, which is missing in the old Kaplan SST data ${ }^{23}$. At lag -2 years (La Nina, Fig. 1a), the SST anomalies are simply revered in sign. When the ENSO lifecycle is at the transition phases from La Nina to El Nino (Fig. 1c) and from El Nino to La Nina (Fig. 1g), which are often called the "neutral phase", significant SST anomalies still exist in Indian Ocean, Atlantic Ocean 


\section{T_ERSST corenso}
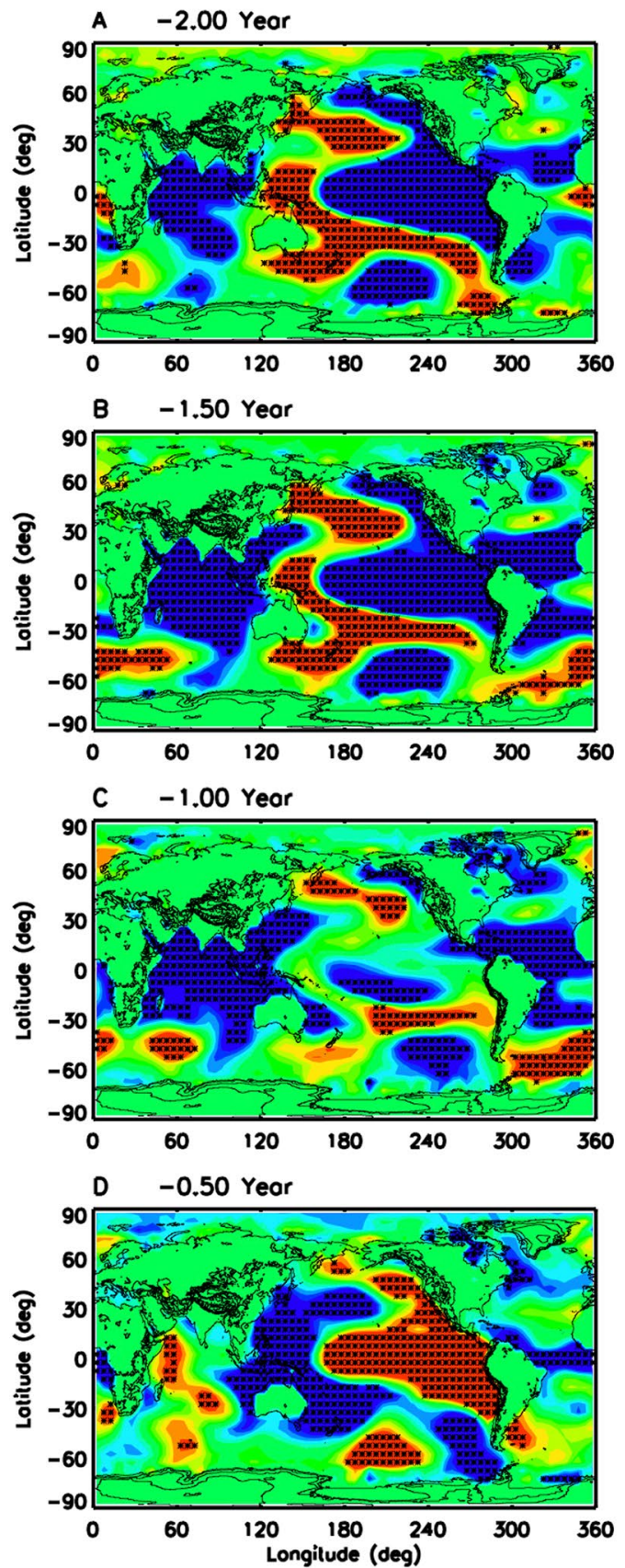

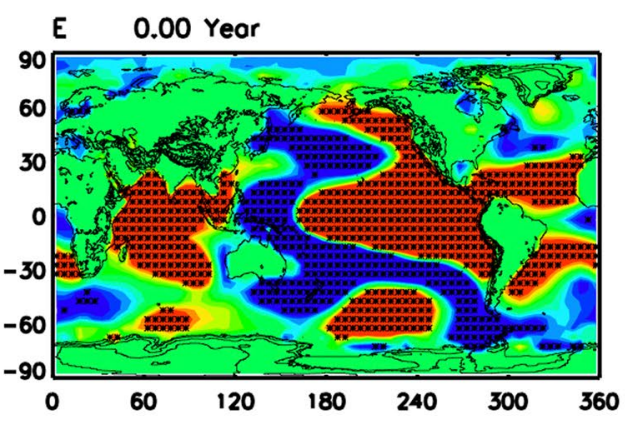

F $\quad+0.50$ Yeor

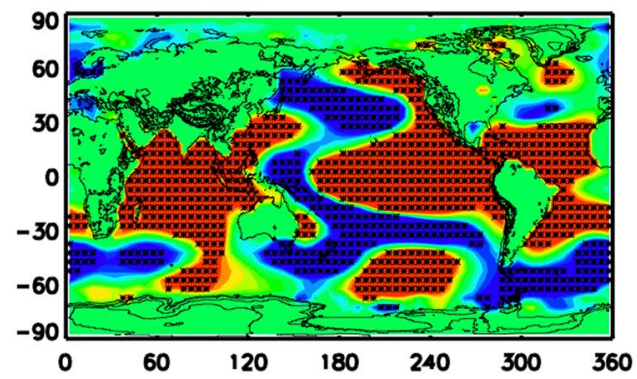

G +1.00 Year

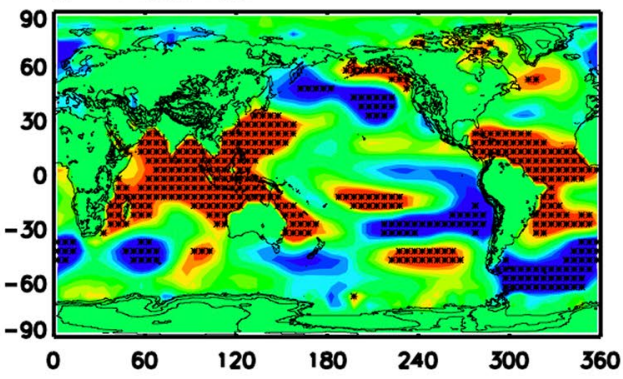

H +1.50 Year

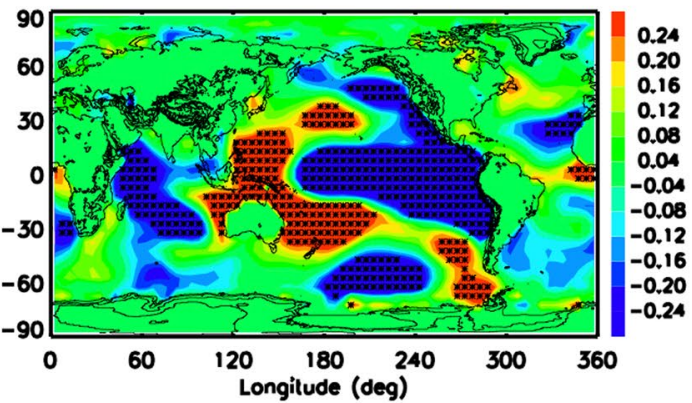

Figure 1. Evolution of global SST associated with ENSO lifecycle. Shadings show lag-correlation of 137 years (1880-2016) of global ERSST anomaly with Nino3.4 SST anomaly from $(\mathrm{A})-2.0$ years to $(\mathrm{H})+1.5$ years. Black stars denote the grids with lag-correlation above $95 \%$ confidence level.

and extratropical Pacific Ocean. It is very important to note that the SST anomalies during the cold-to-warm transition (Fig. 1c) have opposite signs to those during warm-to-cold transition (Fig. 1g). Therefore, they should not be added together into a "neutral phase" composite as in many previous ENSO studies, because the significant anomalies with opposite signs will be cancelled out. Figure 1 suggests that we should use a new four-phase paradigm of ENSO (warm phase, cold phase, cold-to-warm transition, and warm-to-cold transition) to replace the traditional three-phase paradigm (warm phase, cold phase, and neutral phase).

Supplementary Fig. 2 shows a summary of the impacts of ENSO lifecycle on global SST. Different datasets demonstrate consistent significant anomalies over global oceans throughout ENSO lifecycle. Various mechanisms have been proposed for the global SST anomalies associated with ENSO, such as the "atmospheric bridge" mechanism ${ }^{24-26}$, and for persistence of SST anomaly into next year, such as the "re-emergence mechanism"27,28. Dynamically, the observed significant SST anomalies throughout ENSO lifecycle drive temperature, precipitation and atmospheric circulation anomalies over the globe $\mathrm{e}^{29-36}$. 


\section{T_CRUTS corenso}
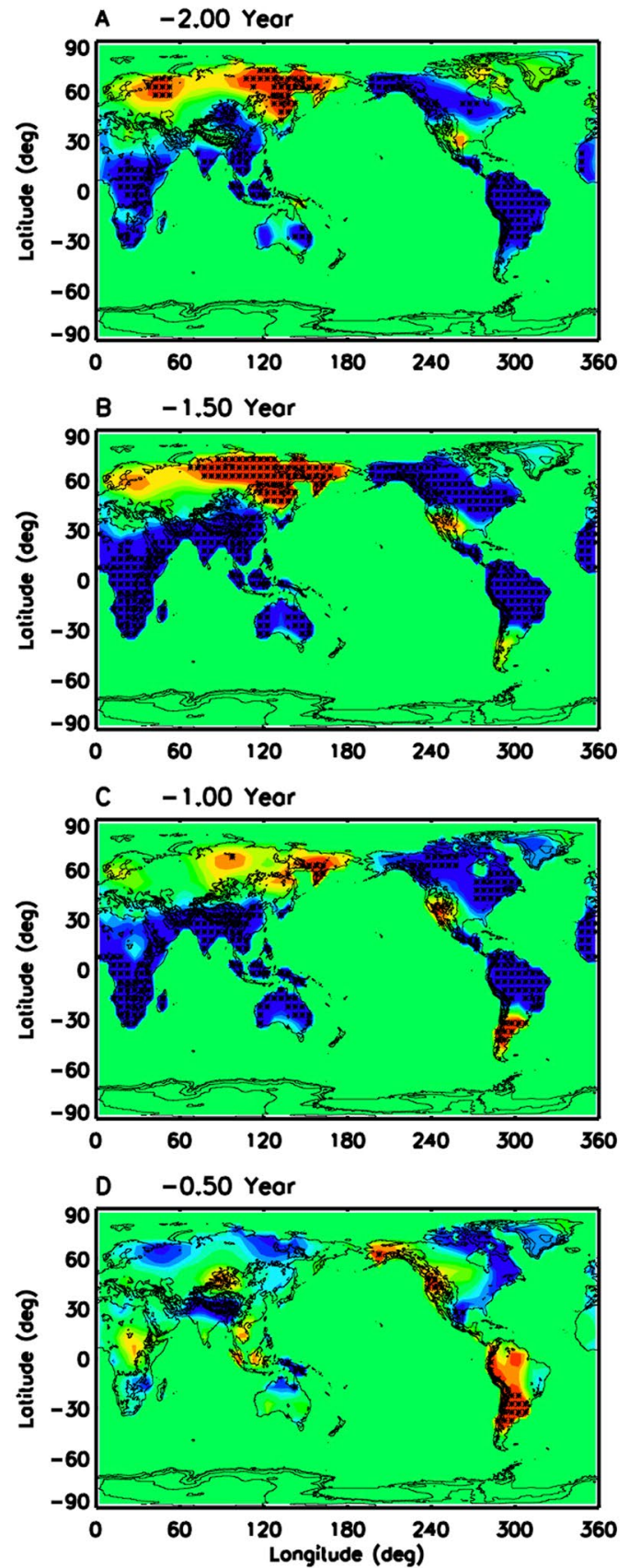
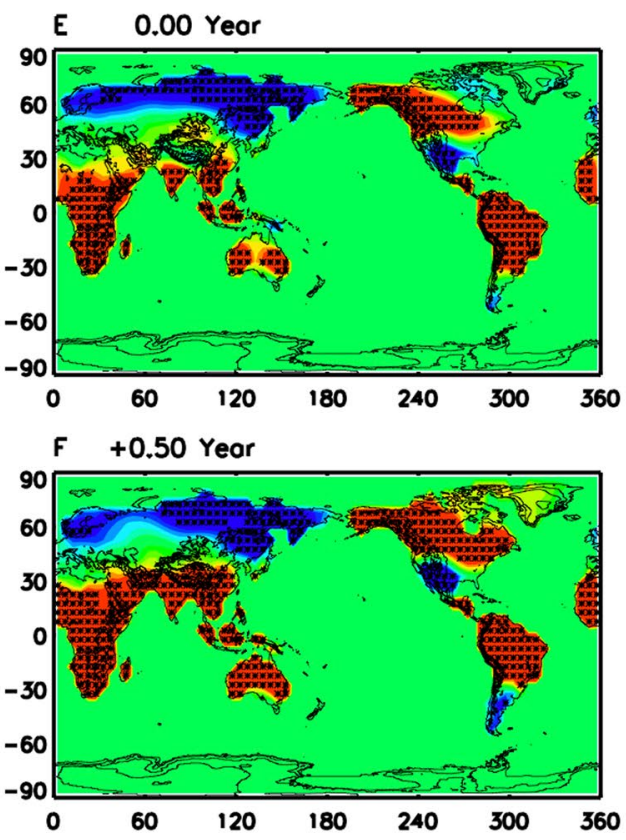

G +1.00 Year

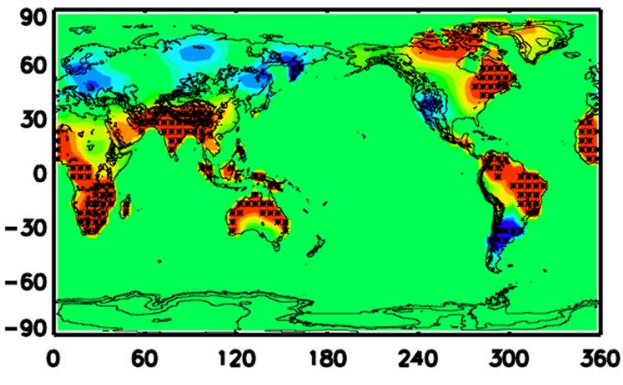

H $\quad+1.50$ Year

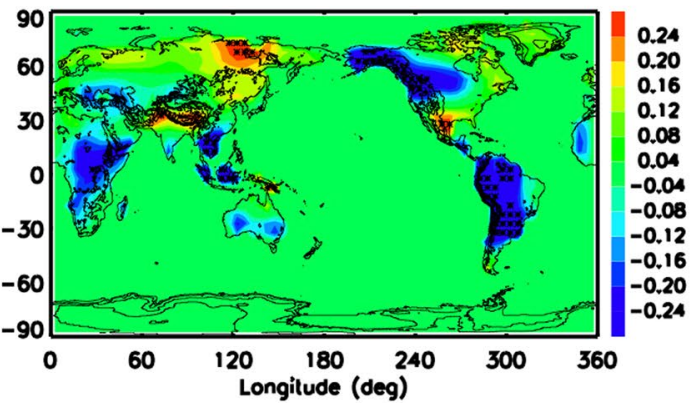

Figure 2. Same as Fig. 1 but for CRUTS land surface air temperature for 1901-2014.

Figure 2 demonstrates the impacts of ENSO lifecycle on land surface air temperature anomalies from 115 years (1901-2014) of CRUTS dataset. The correlation map during El Nino (Fig. 2e) can be compared with the current schematic for December-February (Trenberth et al. ) $^{8}$ since El Nino events tend to be phase-locked to northern winter ${ }^{37,38}$. The new findings from Fig. 2e are significant cold surface air temperature anomalies over Siberia and northern Europe, and warm temperature anomalies over Africa, India, Southeast Asia, West Australia, and part of South America. The correlation map for northern summer after El Nino (lag +0.5 year, Fig. $2 \mathrm{f}$ ) show similar new findings when compared to the current schematic for June-August (Trenberth et al. $)^{8}$. During the transition phase from El Nino to La Nina (Fig. 2g), there are significant warm surface air temperature anomalies over west Africa, south Africa, south Asia, north Australia, northeast United States, and northeast Brazil, but cold temperature anomalies over Argentina. At lag + 1.5 years (Fig. 2h), cold temperature anomalies start to occupy South America, Alaska, western Canada and maritime continent. Evolution after La Nina (Fig. 2a-d) are simply reversed in sign. These results are generally confirmed by ERA-Interim reanalysis 2-meter temperature (Supplementary Fig. 3) and University of Delaware surface air temperature data (not shown). Overall, the summary plots (Supplementary Fig. 4) show significant impacts of ENSO lifecycle on land surface air temperature over all the continents, which 


\section{Precip_GPCC corenso}
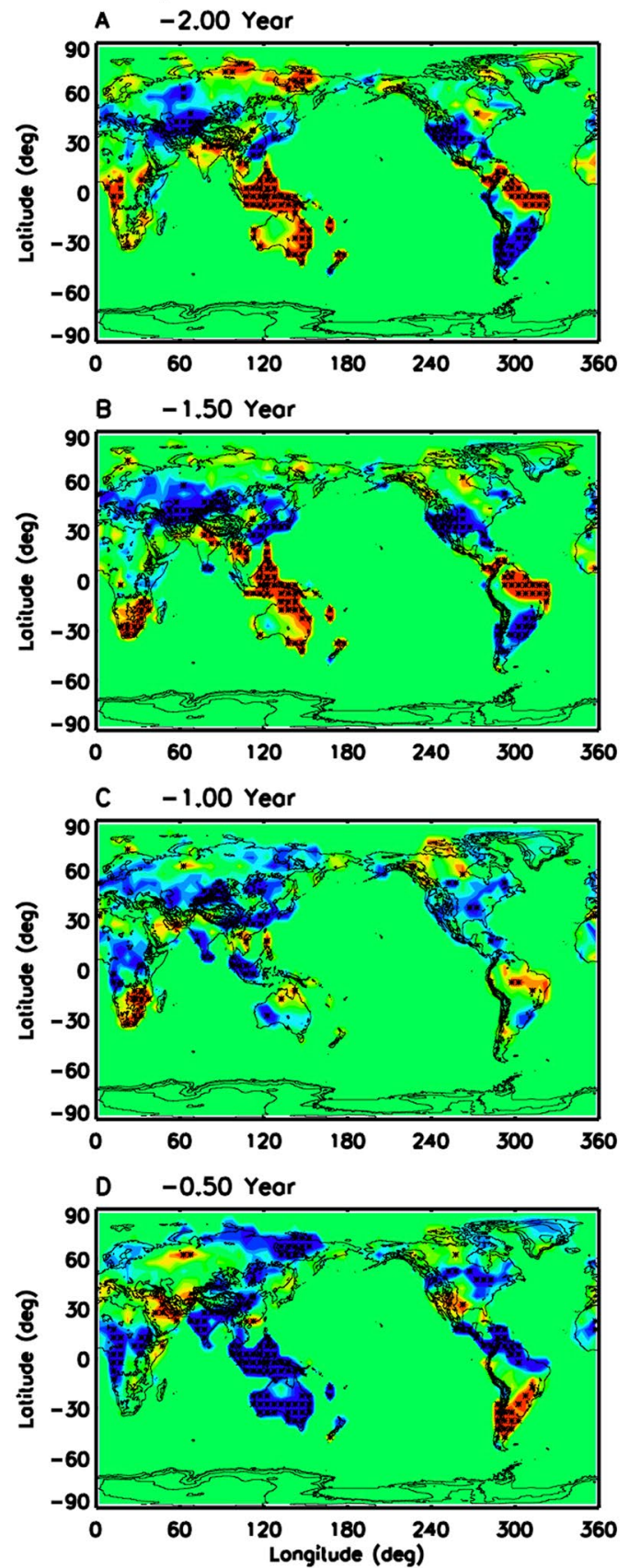

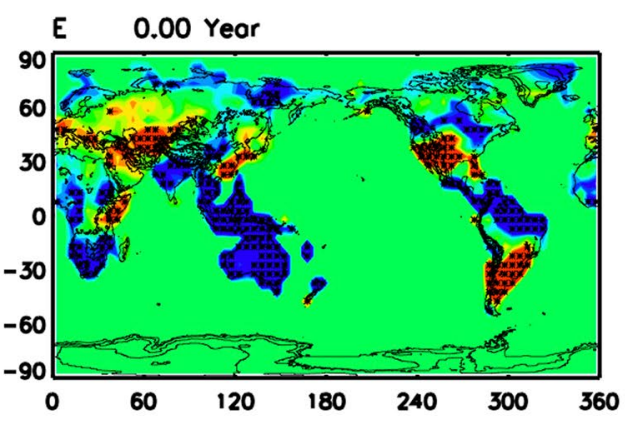

F $\quad+0.50$ Yeor

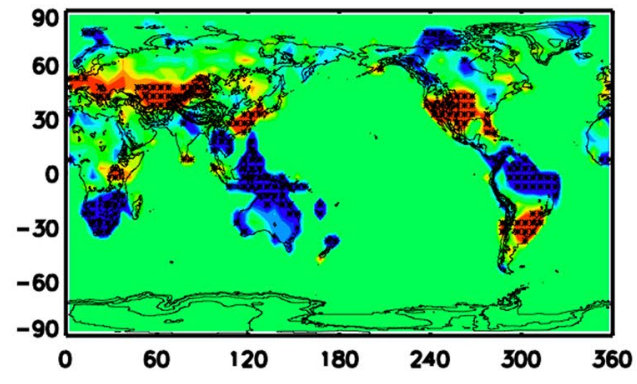

G +1.00 Year

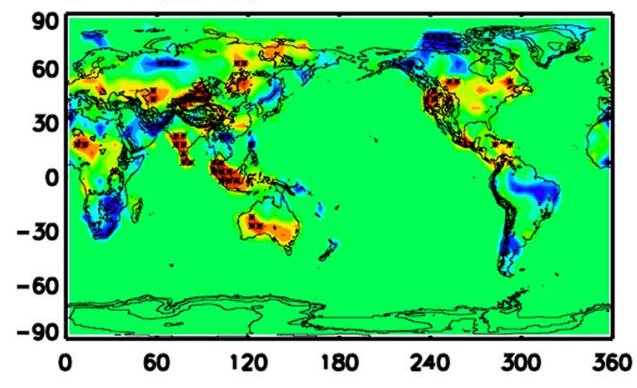

H $\quad+1.50$ Year

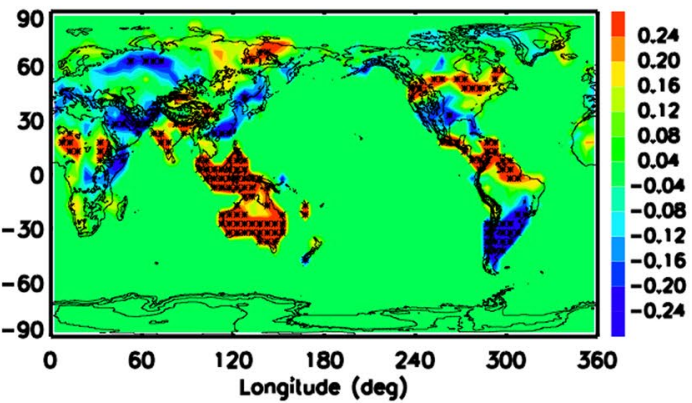

Figure 3. Same as Fig. 1 but for GPCC land surface precipitation for 1901-2013.

are much wider than in the current schematic (Trenberth et al.). The corresponding maps of the linear regression coefficient between surface air temperature anomaly and Nino 3.4 SST anomaly (Supplementary Fig. 5) shows that the largest temperature responses are in NH high latitudes including Canada, Alaska and Russia.

Figure 3 illustrates impacts of ENSO lifecycle on global land surface precipitation based on 114 years (19002013) of GPCC dataset. Comparison of El Nino phase (Fig. 3e) with current schematic (Trenberth et al. ${ }^{8}$ reveals previously unknown strong wet anomalies over southeast China, central Asia and Middle East, and significant dry anomalies over west Africa, India, north Siberia, and central America. Comparison of northern summer after El Nino (lag +0.5 year, Fig. 3f) with the current schematic (Trenberth et al. $)^{8}$ shows newly found significant wet anomalies over central Asia, Middle East and Argentina, and strong dry anomalies over south Africa, southeast Asia and northern Canada. During the transition phase from El Nino to La Nina (Fig. 3g), significant wet anomalies start to develop over south India, maritime continent, west Africa and west Australia, while dry anomalies appear over Middle East. These anomalies grow much wider 6 months later (Fig. 3h). Over other continents such as north America and south America, strong ENSO impacts cover a larger area than what we knew before. For example, the significant ENSO impact on California droughts (Fig. 3a,b,e,f) is not well-depicted 


\section{Global Impacts of the ENSO Lifecycle}

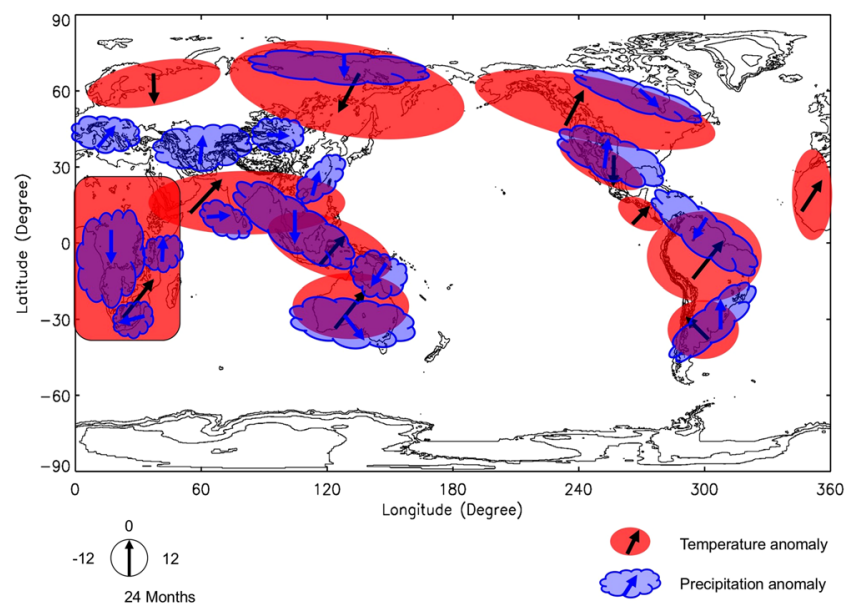

Figure 4. The new schematic of global impacts of ENSO during its whole lifecycle. Red shadings represent significant temperature anomalies, while blue clouds denote significant precipitation anomalies. Arrows denote the time lag of maximum anomalies with respect to Nino3.4 SST anomaly. Phase clock is shown under the schematic. The interval of background topography contours is $1000 \mathrm{~m}$.

in the widely-used schematic. The results from GPCC dataset are generally supported by CRUTS dataset (Supplementary Fig. 6) and merged satellite-gauge GPCP dataset (Supplementary Fig. 7). The corresponding maps of the linear regression coefficient between surface precipitation anomaly and Nino 3.4 SST anomaly (Supplementary Fig. 8) shows that the largest precipitation responses are in the tropics and subtropics.

ENSO has a strong seasonality with the amplitude of Nino3.4 SST anomaly being strongest in November-December-January ${ }^{37,38}$. The surface air temperature anomalies in the summer after El Nino (Fig. 2f) are significantly different from those in the summer before El Nino (Fig. 2d). The precipitation anomalies in the summer after El Nino (Fig. 3f) also have important differences from those in the summer before El Nino (Fig. 3d). Studies using high Nino3.4 SST anomaly during summer tend to combine the two summers together. Our results suggest that it is important to separate the summer after El Nino from that before El Nino since they are at different stages of the ENSO lifecycle.

Figure 4 demonstrates our new schematic of global impacts of ENSO lifecycle on surface air temperature and precipitation. We only include the significant temperature and precipitation anomalies that are supported by at least two different datasets. Comparison of Fig. 4 with the current schematic (Trenberth et al. $)^{8}$ shows that the impacts of ENSO are much wider than those shown in the widely-used schematic. The largest differences are in Europe, Asia and Africa. ENSO significantly modulates surface air temperature in northern Europe, north Asia, south Asia, and entire Africa, and precipitation in southern Europe, central Asia, northern north Asia, and central Africa. For other continents such as north America and south America, significant ENSO impacts cover a larger area than those shown in the widely-used schematic. It is important to note that the so-called "neutral phases" are associated with significant temperature and precipitation anomalies, and anomalies during cold-to-warm transition and warm-to-cold transition have opposite signs.

\section{Methods}

Datasets used in this study are listed in Supplementary Table 1. The ENSO index used in this study is Nino3.4 SST from ERSST dataset. We have tested Nino3.4 SST from COBE2 SST and HadISST datasets and the results are similar. We follow the traditional methods for analysing ENSO's global impacts ${ }^{16-22}$. Linear trend (a single trend calculated for all months together) and composite seasonal cycle are first removed from all datasets. To isolate the interannual ENSO signals from the decadal variability and higher-frequency variability, the anomalies are then filtered with a 3-6 year butterworth filter (Murakami) ${ }^{39}$. We also tested a wider 2-10 year filter and the results are similar. Lag-correlation is calculated with the Nino3.4 SST anomaly. Statistical significance is evaluated following Oort and Yienger ${ }^{40}$.

\section{Data availability}

Datasets used in this study are from NOAA ESRL/PSD Climate Data Archive https://www.esrl.noaa.gov/psd/ and NCAR Research Data Archive https://rda.ucar.edu.

Received: 14 May 2019; Accepted: 9 November 2019;

Published online: 26 November 2019

\section{References}

1. Blanford, H. F. On the connexion of Himalayan snowfall and seasons of drought in India. Proc. Roy. Soc. London 37, 3-22 (1884).

2. Walker, G. T. Correlation in seasonal variations of weather. VIII: A preliminary study of world weather. Mem. Indian Meteor. Dept. 24, 75-131 (1923).

3. Bjerknes, J. Atmospheric teleconnections from the equatorial Pacific. Mon. Weather Rev. 97, 163172 (1969). 
4. Philander, S. G., El Niño, La Nia, and the Southern Oscillation, Academic Press, London, 289 pp.(1990)

5. Wallace, J. M. et al. On the structure and evolution of ENSO-related climate variability in the tropical Pacific: Lessons from TOGA. J. Geophys. Res. 103, 14241-14259 (1998).

6. Deser, C., Alexander, M. A., Xie, S. P. \& Phillips, A. S. Sea surface temperature variability: Patterns and mechanisms. Annu. Rev. Mar. Sci. 2, 115-143 (2010).

7. Messie, M. \& Chavez, F. Global modes of sea surface temperature variability in relation to regional climate indices. J Climate 24, 4314-4331 (2011).

8. Trenberth, K. E. et al. Progress during TOGA in understanding and modeling global teleconnections associated with tropical sea surface temperatures. J. Geophys. Res. 103(14), 291-14 324 (1998).

9. NOAA Climate Prediction Center ENSO website, https://www.cpc.ncep.noaa.gov/products/analysis_monitoring/ensocycle/ elninosfc.shtml (2018)

10. International Research Institute (IRI) ENSO website, https://iri.columbia.edu/wp-content/uploads/2016/05/ElNino_Rainfall.pdf (2016)

11. NOAA Pacific Marine Environmental Laboratory (PMEL) ENSO website, https://www.pmel.noaa.gov/elnino/impacts-of-el-nino (2018)

12. UK Met Office ENSO website, https://www.metoffice.gov.uk/research/climate/seasonal-to-decadal/gpc-outlooks/el-nino-la-nina/ enso-impacts (2016)

13. World Meteorological Organization (WMO) ENSO website and brochure: http://www.wmo.int/pages/prog/wcp/wcasp/documents/ JN142122_WMO1145_EN_web.pdf (2014)

14. U.S. Government Global.gov, https://www.globe.gov/web/el-nino/el-nino-campaign/science-of-el-nino (2018)

15. NOAA Climate.gov, https://www.climate.gov/news-features/featured-images/global-impacts-el-niÒo-and-la-niÒa (2016)

16. Ropelewski, C. F. \& Halpert, M. S. North American precipitation and temperature associated with the E1 Nifio Southern Oscillation (ENSO). Mon. Weather Rev. 11, 2352-2362 (1986).

17. Ropelewski, C. F. \& Halpert, M. S. Global and regional scale precipitation patterns associated with the E1 Nifio/Southern Oscillation. Mon. Weather Rev. 115, 1606-1626 (1987).

18. Ropelewski, C. F. \& Halpert, M. S. Precipitation patterns associated with the high index phase of the Southern Oscillation. J. Clim. 2, 268-284 (1989).

19. Halpert, M. S. \& Ropelewski, C. F. Temperature patterns associated with the Southern Oscillation. J. Clim. 5, 577-593 (1992).

20. Aceituno, P. On the functioning of the Southern Oscillation in the South American sector, I, Surface climate. Mon. Weather Rev. 116, 505-525 (1988).

21. Trenberth, K. E. \& Caron, J. M. The Southern Oscillation revisited: Sea level pressures, surface temperatures, and precipitation. J. Climate 13, 4358-4365 (2000).

22. Yeh, S. W. et al. ENSO Atmospheric Teleconnections and Their Response to Greenhouse Gas Forcing. Reviews of Geophysics 56, 185-206 (2018).

23. Lin, J. L., and T. Qian, Impacts of the ENSO lifecycle on stratosphere ozone and temperature. Geophys. Res. Lett., https://doi. org/10.1029/2019GL083697.

24. Lau, N.-C. \& Nath, M. J. The role of the atmospheric bridge in linking tropical Pacific ENSO events to extratropical SST anom- alies. J. Climate 9, 2036-2057 (1996).

25. Klein, S. A., Soden, B. J. \& Lau, N.-C. Remote sea surface variations during ENSO: Evidence for a tropical atmospheric bridge. J. Climate 12, 917-932 (1999).

26. Alexander, M. A., Lau, N.-C. \& Scott, J. D. Broadening the atmospheric bridge paradigm: ENSO teleconnections to the tropical West Pacific-Indian Oceans over the seasonal cycle and to the North Pacific in summer. Earth Climate: The Ocean-Atmosphere Interaction, Geophys. Monogr., Vol. 147, Amer. Geophys. Union, 85-103.(2004)

27. Alexander, M. A. \& Deser, C. A mechanism for the recurrence of wintertime midlatitude SST anomalies. J. Phys. Oceanogr. 25, $122-137$ (1995)

28. Deser, C., Alexander, M. A. \& Timlin, M. S. Understanding the persistence of sea surface temperature anomalies in midlatitudes. J. Climate 16, 57-72 (2003).

29. Gill, A. Some simple solutions for heat-induced tropical circulation. Quart. J. Roy. Meteor. Soc. 106, 447-462 (1980).

30. Zhang, Z. \& Krishnamurti, T. N. A generalization of Gill's heat-induced tropical circulation. J. Atmos. Sci. 53, 1045-1056 (1996).

31. Hoskins, B. J. \& Karoly, D. J. The steady linear response of a spherical atmosphere to thermal and orthographic forcing. J. Atmos. Sci. 38, 1179-1196 (1981)

32. Simmons, A. J. The forcing of stationary wave motion by tropical diabatic heating. Quart. J. Roy. Meteor. Soc. 108, 503-534 (1982).

33. Held, I. M., Stationary and quasi-stationary eddies in the extratropical atmosphere: Theory. Large Scale Dynamical Processes in the Atmosphere, R. P. Pearce \& B. J. Hoskins, Eds., Academic Press, 127-168 (1983)

34. Held, I. M., Ting, M. \& Wang, H. Northern winter stationary waves: Theory and modeling. J. Climate 15, 2125-2144 (2002).

35. Hoerling, M. P. \& Kumar, A. Atmospheric response patterns associated with tropical forcing. J. Climate 15, 2184-2203 (2002).

36. Kushnir, Y. et al. Atmospheric response to extratropical SST anomalies: A synthesis and evaluation of recent results. J. Climate 15, 2233-2256 (2002).

37. Rasmusson, E. \& Carpenter, T. Variations in tropical sea surface temperature and surface wind fields associated with the Southern Oscillation/El Nino. Mon. Wea. Rev. 110, 354-384 (1982).

38. Larkin, N. K. \& Harrison, D. E. ENSO warm (El Nino) and cold (La Nina) event life cycles: Ocean surface anomaly patterns, their symmetries, asymmetries, and implications. J. Climate 15, 1118-1140 (2002).

39. Murakami, M. Large-scale aspects of deep convective activity over the GATE area. Mon. Wea. Rev. 107, 994-1013 (1979).

40. Oort, A. H. \& Yienger, J. J. Observed long-term variability in the Hadley circulation and its connection to ENSO. J. Climate 9 , 2751-2767 (1996).

\section{Acknowledgements}

Datasets used in this study are from NOAA ESRL climate data archive and NCAR Research Data Archive. This study was supported by NSF Grant AGS-1347132.

\section{Author contributions}

J.L. and T.Q. jointly analysed the datasets, wrote the manuscript text and prepared all the figures.

\section{Competing interests}

The authors declare no competing interests. 


\section{Additional information}

Supplementary information is available for this paper at https://doi.org/10.1038/s41598-019-54090-5.

Correspondence and requests for materials should be addressed to J.L.

Reprints and permissions information is available at www.nature.com/reprints.

Publisher's note Springer Nature remains neutral with regard to jurisdictional claims in published maps and institutional affiliations.

(c) (i) Open Access This article is licensed under a Creative Commons Attribution 4.0 International License, which permits use, sharing, adaptation, distribution and reproduction in any medium or format, as long as you give appropriate credit to the original author(s) and the source, provide a link to the Creative Commons license, and indicate if changes were made. The images or other third party material in this article are included in the article's Creative Commons license, unless indicated otherwise in a credit line to the material. If material is not included in the article's Creative Commons license and your intended use is not permitted by statutory regulation or exceeds the permitted use, you will need to obtain permission directly from the copyright holder. To view a copy of this license, visit http://creativecommons.org/licenses/by/4.0/.

(c) The Author(s) 2019 